\title{
Vesna Ivezić
}

Centar za filozofiju medija Zagreb, Udruga za promicanje ljudskih prava, slobobe i kvalitetnog života IDIA

Zagreb, Hrvatska

vesna.ivezic9@gmail.com

\section{Strah od smrti i težnja ka besmrtnosti - vječne paradigme čovjekovog suočavanja sa smréu}

\section{Sažetak}

Čovjeka kroz povijest prati smrt, koja usprkos činjenici da smo smrtni, nije dostupna ljudskom iskustuu, što je oduvijek izazivalo različite spekulacije o njenoj prirodi, te potrebu za objašnjenjem onoga što slijedi iza. Strah od smrti je strah od nepoznatog, raspadanja, nestajanja. Odnos prema smrti, jednako kao i čovjekovo poimanje svijeta, sukladan je stanju društva, od duboke povezanosti života i smrti u arhaično doba, pa da sve većeg odvajanja, što je u skladu s bazičnom dihotomijom koja karakterizira ljudski um, i sve je veća. Čovjek sve više gubi osjećaj za povijesno vrijeme, kontinuitet, i povezanost postojanja, te se očajnički drži za život. Vječna težnja ka besmrtnosti, prije u domeni religïje, sad je prebačena na vjeru u uspjeh znanosti. Novije doba karakterizira izbjegavanje bolesti i starenja, kult predaka zamijenjen je kultom mladosti, a u okviru čovjekove usmjerenosti na prevladavanje smrti naglašena je potreba samorazvoja, kao jedina šansa izmirenja s činjenicom vlastite smrtnosti. U vrijeme velikih katastrofa:, ratova, elementarnih nepogoda, potresa, epidemija, smrt je vidliuija, sveprisutna. Strah od smrti pokazuje se utemeljen u stvarnosti.

Ključne riječi: smrt, poricanje smrti, strah od smrti, kultura mladosti, samorazvoj, pandemija. 
Trenutak smrti je zastrašujući zbog toga što se ne zna kuda se ide, dakle, zbog neznanja. Put prema nepoznatom cilju je zastrašujući, to je srah od nepoznatog. Isto je kao kad netko želi ići na vrlo mračno mjesto i boji se jer ne zna što u mraku može očekivati. Ali kad jednom upozna mjesto, drugi put će unatoč tami biti manje straha. Dobro je da se čovjek već za života sprijatelji s procesom umiranja, jer onda u trenutku smrti neće biti straha od gubitka života, što je ustvari samo gubitak forme. Preveliko prijanjanje za formujedan je od uzroka straha. Ako se nikad prije s time ne zbližimo, onda u trenutku smrti više nema takve mogućnosti iodlazak bez ikakvog znanja i bliskosti s procesom u mnogih izaziva šok, agoniju i veliki strah. Smrt nije ništa drugo nego prijelaz u novo postojanje, novo stanje uma. Ništa ne umire, nego je to prirodan proces sličan onom kad nakon duboke zime nastupi proljeće i ponovo dolazi život. To je kao izmjena dana i noći. Tijelo jednom dotraje i ostari, a u svojoj biti mi nismo tijelo koje je kao košuljica koju odbacujemo u trenu smrti i oblačimo novu ulaskom u slijedeći život. U razumijevanju prave prirode života $i$ smrti leži razumijevanje smisla postojanja.

(Lama Ven. Ayang Rinpoche) $)^{70}$.

\section{Uvod}

Usprkos činjenici da smo smrtni, smrt nije dostupna ljudskom iskustvu, što je tijekom povijesti uvijek izazivalo različite spekulacije o njenoj prirodi te potrebu za objašnjavanjem onoga što slijedi iza. Strah od smrti prvenstveno je strah od nepoznatog, a očituje se kao strah od nestajanja. Ovaj rad bavi se fenomenom čovjekovog susreta sa smrću i potrebom da se raznim vidovima poricanja spoznaje o vlastitoj konačnosti odagna iz svijesti, te da se dostigne besmrtnost. Odnos prema smrti uvijek je, jednako kao i čovjekovo poimanje svijeta koji ga okružuje, bio sukladan stanju društva. U arhaičnim društvima život i smrt bili su duboko povezani, a kasnijim raslojavanjem društva dolazi do sve većeg odvajanja čovjeka od svijeta predaka, čime i fenomen smrti postaje sve udaljenijim od života, suvremeni je čovjek na sve načine pokušava negirati i izbjeći. Smrt je za čovjeka u svim stadijima njegovog razvoja bila tajanstvena i zastrašujuća činjenica, s tim da je čovjek arhaičnog doba u odnosu na današnjeg ipak imao prijateljskiji odnos prema smrti, u tom smislu da je, iako teška srca, prihvaćao činjenicu vlastite smrtnosti kao neminovnu. Glavni pokretač straha od smrti je oduvijek bio strah od nepoznatog i strah od nestajanja, nestajanja svega sto je pojedinac tijekom života pažljivo gradio (znanja, uvjerenja, umišljaja), dakle odbijanje smrti spada u domenu ega, s tim da je arhaični čovjek svoju smrt prepuštao vračevima, šamanima i svećenicima, pojedincima koji su bili „zaduženi“ za komunikaciju s onostranim, svijetom mrtvih, dok je suvremeni čovjek, slijedom procesa racionalizacije imanentnog razvoju ljudskog društva pitanja smrti na razne načine sve više pokušavao uzeti u svoje ruke. Ti pokušaji su sve do današnjeg dana pokazali bezuspješnima.

70 Lama Ven.Ayang Rimpoche, u travnju 2003. na zagrebačkoj Medvednici održao je seminar Phowa meditacije, svojevrsno desetodnevno budističko povlačenje, gdje su se polaznici mogli upoznati s metodom prijelaza iz jednog stanja svijesti u drugo, kao metodom boljeg razumijevanja smrti. Lama Ven. Ayang Ripoche pripada Trikung Kagyu školi tibetanskog budizma poznatoj po tradiciji Phowa prakse, budističkog učenja koje se bavi smrću, i već više od trideset godina putuje svijetom prenoseći meditacijska iskustva./ Vesna Ivezić, Novi list, travanj 2003. 
U novije vrijeme, vrijeme potresa i epidemija čemu svjedočimo odnedavno (2020. i 2021.), strah od smrti se pojačava jer pokazuje se utemeljenim u stvarnosti, smrt je vidljivija, umire se češće nego kad su vremena neopterećena katastrofama. Svjedočimo joj svakodnevno, u čemu veliku ulogu imaju mediji koji prenose poruku, slike, predviđanja i oblikuju sliku svijeta prikazujući ga manje ili više „opasnim“ i smrtonosnim. Strah od smrti postaje moćno sredstvo kontrole, moći i vladanja.

\section{Smrt i kultura - konačna pobjeda prirode}

Počet ćemo tezom Louisa Vincenta Thomasa ${ }^{71}$ da je stav prema smrti crta kojom čovjek djelomično izmiče prirodi i postaje životinja prožeta kulturom, te koliko je do sada poznato, jedino je biće na svijetu koje posjeduje svijest o vlastitoj smrtnosti.

Što stoji iza primjedbe o čovjekovom djelomičnom izmicanju iz područja prirodnog, nauštrb ulaska u područje kulture? Priroda i kultura, dva pojma najsloženija i najsveobuhvatnija po širini i raznolikosti kojima zahvaćaju stvarnost naoko su suprotstavljena jer, smatra se da kultura preobražava prirodu, ono što je izloženo procesu ljudskog djelovanja gubi na prirodnosti. Prema shvaćanju Edgara Morina $^{72}$ kulturnima se smatraju sve radnje i vrijednosti koje služe čovjeku da ga štite od nasilja prirodnih sila! Pitanje je kako činjenica postojanja svijesti o smrtnosti ima utjecaja na čovjekov odnos spram smrti, koliko ga može zaštititi, i može li joj čovjek zbog toga (makar djelomično) izmaći. Ljudi su od pamtivijeka pokušavali dati odgovor na to pitanje.

Osim stalnog podsjećanja na njenu neupitnost (,sjeti se da si prah i u prah ćeš se vratiti“ ili da „posmrtno zvono svima zvoni“), činjenice da se smrt nikako ne može izbjeći, („memento mori“ zvoni svima bez razlike) i da je umiranje jedina izvjesnost u cijeloj toj priči, znanja da to znači prestanak životnih funkcija bića, kraj, o samoj prirodi smrti i umiranja nema pouzdanih spoznaja iz jednostavnog razloga što još do sada nitko tko bi pouzdano mogao svjedočiti o tome nije bio mrtav. Iako su u novije vrijeme popularna svjedočanstva iz domene „tik do smrti“, koja uz razne tehnike „ulaženja u sebe“, meditacije ili postupaka uz korištenje psihoaktivnih droga koji kako se smatra simuliraju stanja ulaženja u smrt, neposredne blizine smrti i smrti same, ona ipak nisu stanje smrti. Činjenica da je život neprekidno izložen tom krajnjem susretu, da sve što živi mora i umrijeti jer takav je zakon postojanja, uvijek iznova u nama budi osjećaj tjeskobe, nesigurnosti i straha zbog stalne prisutnosti nepoznatog, neizvjesnog kraja, nestajanja. Iako se sa smrću susrećemo svakodnevno, mi o njoj ne želimo razmišljati.

U različitim tradicijama odnos prema smrti zavisio je od osnovnih shvaćanja ljudske smrtnosti, ali svim ljudima je zajedničko da čine sve kako bi odagnali pomisao na ono što na kraju svakog životnog puta ima biti.

71 Louis Vincent Thomas, Antropologija msrti, I i II, Prosveta, Beograd 1980.

72 Edgar Morin, Čovjek i smrt, Scarabeus - naklada, Zagreb 2005., str. 294 
No smrt je važna stvar, naročito za one koji su u starijoj dobi i time su joj, kako se smatra - bliže. Pitanje smrti čovjeku postavlja važna pitanja o životu i postojanju na koja je dužan odgovoriti ${ }^{73}$ da bi izbjegao stanje beznađa i ništavila koje je najmračnija stavka pri pomisli na ono što na kraju svakog puta ima biti, na nestajanje koje time pokazuje i besmisao ljudskog postojanja, najstrašnija je ideja koja od pamtivijeka prati čovjeka. Jung smatra da bi čovjek trebao izgraditi mit o smrti, jer razum mu ne pokazuje „ništa osim mračne jame u koju se spušta“, te ako vjeruje u taj mit (pri čemu će biti jednako u pravu ili u krivu kao i onaj koji ne vjeruje, ali će biti u boljoj poziciji od njega koji kroči ravno prema ništavilu), tada će uz vjeru u arhetip slijedom staze života mirno koračati u njoj ususret. Zemaljski život je izuzetno važan zbog toga što se u životu može podizati opća razina

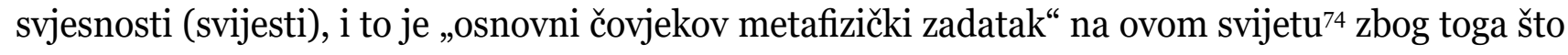
najveći stupanj svjesnosti koji je u životu postignut čini gornju granicu znanja neophodnog za daljnje putovanje u svijet mrtvih. To je ono što ljudsko bice „prenosi“ sa sobom. Život zato treba iskoristiti na najbolji mogući način. „Imate samo ovaj jedan život, a (tek!) kasnije ćete baštiniti život vječni ${ }^{75^{\prime \prime}}$, govorio je Isus misleći pri tom da se čovjek za života treba truditi da razvije svoj puni potencijal. Jung uvodi pojam individuacije, što označava proces psihičkog sazrijevanja osobe, samoostvarivanje, postizanje cjelovitosti. Smatra se da čovjek na svijetu živi podijeljen, rascjepkan, odvojen od svoje ljudske biti, te mu je najvažniji zadatak u životu samorazvoj u smislu postizanja cjelovitosti. Jung uostalom smatra da uspješno dovršen proces individuacije ${ }^{76}$ uključuje i razrješenje problema smrti, jer sa razvijenom sviješću o smrti ide i svijest o dragocjenosti svakog trenutka života, potreba za" netraćenjem“ života. "Horror vacui” koji zjapi u slutnji nestajanja, u "natura abhorret vacuum” "77 nalazi svoje razrješenje; „pustite mrtve neka pokapaju svoje mrtvace, a vi krenite prema životu“, novozavjetna je preporuka koja sugerira orijentaciju prema životu. Prema tome, u kojoj se mjeri povežete sa životom, uspijete u ostvarivanju njegove punine, utoliko ćete izbjeći užas zbog nestajanja, praznine.

Pri pomisli na skoru smrt čovjek uvijek pomišlja na ono što je propustio učiniti, i strah od smrti je u pravilu izraz neuspjeha življenja života. U času odlaska čovjeku dolazi do svijesti sve ono što smatra da ga još čeka, da još nije ostvario. ${ }^{78}$ Za sebe traži određeni rok u kojem bi bio pošteđen da dovrši ono što još nije, i strah od smrti je strah da ćemo nestati a da nismo ostavili svoj trag u sveukupnoj energiji svijeta.

Prema iskazu onih koji su doživjeli iskustvo „tik do smrti“ može se zaključiti da posljednje što ostaje na životu je svijest o vlastitom ,ja“.Često se spominje neobičan osjećaj gledanja svoje vlastite prošlosti

73 Carl Gustav Jung, Sjećanja,snovi, razmišljanja, Fabula Nova, Zagreb 2004, str. 417

74 C. G. Jung, Sjećanja, snovi, razmišljanja, str. 424

75 Mt, 19,29

76 Individuacija (lat. Individuum, jedinka) u svom prvobitnom značenju je "upojedinjavanje“, izdvajanje jedinke iz nečeg općeg, promatranje nekoga ili nečega prema njegovoj osobnosti. Pojam nalazimo u psihologiji Karla Gustava Junga, čime se bavi i njegova učenice Jolande Jacobi u knjizi „Jungov put individuacije“ .

77 lat. "priroda zazire od praznine"

78 Erich Fromm, Čovjek za sebe, Naprijed, Zagreb 1977. 
koja se odvija „kao na filmu“, i kako Morin ${ }^{79}$ ističe, to je pokazatelj postojanja individualnosti koja na pragu smrti obuhvaća samu sebe i pokazuje se u punom sjaju posljednji put, samo jedanput kao posljednja jasna misao. To je posljednja prilika preispitivanja svrhe vlastitog postojanja, i ljudi koji su dio toga iskusili, isticali su kao najstrašniju činjenicu da su uvidjeli da im je veći dio života prošao u ispraznosti, što je onda valjda razlog opće poznatoj činjenici da je u pravilu svatko tko je doživio stanje „tik do smrti“ promijenio svoj dotadašnji način života i shvaćanje njegove vrijednosti. Na tu temu mogla bi se parafrazirati poznata izreka „pitat će te starost gdje ti je bila mladost“ u „pitat cee te smrt gdje ti je bio život!“

Čovjek se za vrijeme svog cjelokupnog postojanja bori da ovlada prirodom i smrt je za njega neosvojivo područje, možda i jedino čija ga neizbježnost uvijek podsjeća na vlastiti poraz. Smrt je potvrda čovjekovog konačnog poraza u borbi s prirodom, priroda odnosi konačnu pobjedu nad kulturom! ${ }^{80}$

Jezikom kulture koja pridaje pojmu razna značenja, smrt se može tumačiti na razne načine: kao oslobođenje od patnje zbog bolesti ili teškog života, kao prirodni biološki kraj, kao mučeništvo, herojstvo ili žrtvovanje u neku svrhu, kao simbol kraja, beskorisnosti i ništavila. No što god mi govorili i koja god značenja pridavali, na kraju ipak nastupa smrt, dio prirodnog procesa koji, prema riječima suvremene britanske filozofkinje koja se bavila pitanjima kulture, prirode i ljudskog postojanja Kate Soper ${ }^{81}$, označava materijalnu sliku procesa neovisnog o ljudskoj djelatnosti ma koliko se mi trudili da ju izbjegnemo.

Umrijeti dobro i neprimjetno, brza, laka i trenutačna smrt ili lagano kopnjenje u starosti, raspadanje u bolesti, ili pak izopačeni načini umiranja kakvih je prepuna povijest - što izabrati, kako izbjeći! Čovječanstvo još od pamtivijeka bezuspješno traga za vječnim životom, ali uz sav napredak medicine, „naš se maksimalniživotni vijek uporno ne miče od oko 120 godina, unatoč svim našim naporima“82 Smrt kao prirodna selekcija, ,zbunjujući izum prirode “ ${ }^{83}$ kojim se majčica zemlja rješava prevelikog tereta, predmetom je mnogih istraživanja od početaka čovječanstva, a „eliksir života“ oduvijek je u svim epohama bio jedan od najtraženijih artikala, što se nije promijenilo niti do danas. Još od Gilgamešovih traganja za vječnim životom, iz početaka zabilježene povijesti, gdje čudotvorna biljka uručkom kralju na kraju klizne kroz prste "poput mita“84, neuhvatljivost pouzdanog sredstva za ostvarenje vječnog života ili bar njegovog produljenja problem je koji je na povijesnoj sceni jedan od ključnih predmeta bavljenja čovjekovog, i artikuliran u obliku neobičnih, često bizarnih rješenja:

79 E. Morin, Čovjek i smrt, str. 52

80 Terry Eagleton, Teorija i nakon nje, Algoritam, Zagreb 2002.

81 Kate Soper, What Is Nature?, Oxford, 1995:132-3) u T. Eagleton, Teorija i nakon nje

82 Nicka Lane, Uspon života, Planetopija, Zagreb 2012., str. 227

83 N. Lane,Uspon života, str. 227

84 Ibid., str. 227 
Sveti Gral, mljeveni rog jednoroga, nasjeckani testisi jarca, ekstrakt psećih i zamorčevih testisa, ${ }^{85}$ krv djevica, i mnogi drugi maštoviti prijedlozi koji se u novije vrijeme javljaju u obliku legendi o čudotvornim jogurtima s Kavkaza, posebnim režimima prehrane, stila života, pa sve do najnovijih dostignuća medicine u obliku (opet!) različitih eliksira za produljenje života, pa do postupaka za odgađanje smrti u slučajevima teških bolesti. Zanimljivo je razmatranje brazilskog bioetičara i teologa Lea Passinija ${ }^{86}$ o pojmu distanazije ${ }^{87}$, kao metode produžavanja života pod svaku cijenu. Prema autoru, distanazija je akademski termin koji ima isto značenje koje bismo mogli izraziti kao "beskorisna medicina" ili "beskorisna terapija koja nanosi bol". Dakle, riječ je o liječenju koje ne daje nikakve pozitivne rezultate. Autor navodi da se radi o 'terapeutskoj upornosti' ${ }^{88}$ koja prolongira smrt i patnju, produžava proces umiranja. Danas bolesnici sve više postaju zatočenici suvremene medicinske tehnologije i sve manje im se pomaže da umiru s više dostojanstva i manje boli. Stoga autor smatra da bi u bolnicama morala prevladati drukčija moralna svijest i pristup terminalnim bolesnicima.

\section{Smrt i religija - Spasenje kao vrhovna paradigma besmrtnosti}

Religija je oblik kulture koji se do sada pokazao najmoćnijim u procesu povezivanja transcendentalnih vrijednosti vezanih uz značenje i smisao smrti u uobičajenim ljudskim praksama. Ars moriendi, umijeće umiranja, smatralo se vještinom koja se mogla naučiti od za to posebno obučene osobe, mudraca. Odnos prema smrti ljudi su izražavali vjerovanjem o zagrobnom životu, seljenju duša, reinkarnaciji, „putovanjima“ o kojima su postojali razni priručnici (Tibetanska knjiga mrtvih, Egipatska knjiga mrtvih). U najznačajnijim religijskim praksama čovječanstva odnos prema smrti te pogledi na njen smisao različiti su, i ovise o različitosti kultura i njihovih pokušaja da činjenicu smrti integriraju u sveobuhvatno shvaćanje života.

Na Istoku su najsnažniji hinduizam i budizam, gdje se u najstarijim spisima hinduističke tradicije smrti poklanja malo pažnje, te životu okrenut svjetonazor naglašava odlaganje smrti ili ima tek nejasnu predodžbu u nadživljavanju smrti, dok se budizam razlikuje po tome što smatra da je ljudsko postojanje podčinjeno silama smrti i patnje, i ne postoji niti jedan aspekt bića koji bi bio u stanju izbjeći lanac uzroka i posljedica, života i smrti, te nestajanja. Pošto je uzrok svih patnji naša vlastita žudnja, tako je i patnju zbog smrti moguće izbjeći otklanjanjem žudnje za nepromjenjivim (besmrtnošću) i moguće je postići smirenje u nirvani ${ }^{89}$.

85 „Francuski biolog Charles Brown Sequard, u pariškoj Societe de Bologne, ubrzgao si je ekstrakt psećih i zamorčevih testisa, i izvijestio o povećanju snage i mentalnih sposobnosti, demonstrirajući to pred zapanjenom publikom mladenačkim mlazom urina“", (Ibid., str. 227)

86 Leo Passini, „Distanazija ili dokle produžavati život“, u Luka Tomašević, Do kada produživati život?, Služba Božja, 45,br.2, Zagreb 2004., str. 143-146

87 distanazija, grč, „dys“ - ne, i „thanatos“ - smrt; i doslovno bi značila 'ne-smrt' ili protivljenje smrti, a lansirana je od strane američkih bioetičara.

88 ibid. str. 144

89 Nirvana je središnji koncept budizma. Označava stanje potpunog smirenja gdje je pojedinac oslobođen vječne patnje ciklusa smrti i ponovnog rođenja. 
Na Zapadu su se tri najznačajnija shvaćanja smrti razvila u okviru platonizma, judaizma i kršćanstva. Platonova filozofija je po pitanju shvaćanja smrti imala najviše odjeka u zapadnom svijetu, zbog toga što Platon ističe da zadatak filozofije nije samo da nam otkrije istinu, nego i da oslobodi dušu za njeno vječno postojanje..$^{90}$ Platonov učitelj Sokrat u času svoje smrti u razgovoru s učenicima ${ }^{91}$ navodi razloge za vjerovanje o besmrtnosti duše, što najviše ovisi o znanju. Sokrat govori o seljenju duša nakon smrti iz tijela u tijelo. Grčki pojam metampsihoze ${ }^{92}$, selenja duša nakon smrti iz tijela u tijelo, potiče iz orfičke mitologije. Nizom reinkarnacija ${ }^{93}$, duša se sve više čisti, što je dobar proces. Sokrat u času smrti od učenika traži da prinesu malenu žrtvu (pijetla), jer time želi pokazati kako smrt za njega znači ozdravljenje. Nije na odmet još spomenuti filozofa Epikura i njegov originalan stav prema smrti. Naime, začuđen činjenicom da ljudi toliko pažnje posvećuju „problemu“ smrti, da mogu provesti cijeli život strepeći zbog činjenice da su smrtni, da će kad-tad umrijeti, izjavljuje da je strah od smrti besmislen, jer dok „ima nas nema smrti, a kad nastupi smrt nema nas“.

Kad netko premine, njega više ne bude..$^{94}$ Judaizam pojam smrti veže uz pojam kazne, ali u tom slučaju smrt dolazi uz obeštećenje u vidu znanja o dobru i zlu, te moći i odgovornosti u donošenju odluka. To vjerovanje se razaznaje već u priči iz Knjige Postanka $(2,4-3,24)$, gdje Bog kažnjava Adama i Evu izgonom iz rajskog vrta, te na kraju i smrtnošću. Čovječanstvo je baštinik smrti usljed Adamovog grijeha, smrt je svjedok prisutnosti grijeha na zemlji. Napustivši Rajski vrt, Adam i Eva postaju stvarna ljudska bića, pa je tim slijedom, i smrt jedan od mnogih „darova“ koje baštine kao ljudska bića. Sotona ih pridobiva na neposluh Bogu obećanjem besmrtnosti95, ali Adam i Eva gube prvobitnu svetost koju su imali kao stanovnici rajskog vrta i dospijevaju u materijalni svijet, svijet rađanja, rasta i umiranja.

U novozavjetnom dijelu kršćanstva, iz izreka pripisanih Isusu, može se razabrati da je on prvenstveno opredijeljen za život, te da Bog nije „Bog mrtvih, nego Bog živih“" ${ }^{96}$, središnja točka njegovog učenja je uskrsnuće, simbol još jednog opredjeljenja za život, a ideja vječnog života je vjerovanje u izbavljenje

90 Težište je Platonova razmatranja u dokazivanju eĩdosa duše što uključuje životnost i isključuje smrtnost. Postupak se odvija u dva koraka: ponajprije se dokazuje njezina besmrtnost (athánaton), a zatim i njezina neprolaznost (anólethron), pritom imajući u vidu dva načina prolaženja, prvi se odnosi na minuće, drugi na propadanje. Pre-minuće je zapravo promjena mjesta, a ovo potonje uključuje Ništa, tj. propadanje, jer za razliku od života, što je ono besmrtno, duša je isto tako i neprolazna, jer nikada ne može ne biti biće što nakon smrti odlazi nekamo drugamo., Platon, Fedon, priredio Josip Talanga (redigirani prijevod Kolomana Raca), 57a-118a17,/23.02.2012.

91 Fedon je dijalog koji daje pouku o tome što je smrt i kako se umire u odnosu na značenje pojma ideje kao idealnog i besmrtnog bitka, te načina spoznaje ideje uz pomoć dijalektike kao vrhunca misaonog djelovanja kome polazi za rukom povezati jedno i mnoštvo. Ideja povezivanja mnoštvenog, pojedinačnog s Jednim, vječnim, osnova je daljnjih razmatranja o jedinstvenosti, cjelovitosti i povezanosti cjelokupnog postojanja koje uključuje i čovjeka, koju nalazimo kroz čitavu povijest čovječanstva sve do današnjih dana.

92 „selenje duša“

93 Lat. re in carno, ,ponovo u tijelo“

94 Ps 39,14; Job,7,8,21;7,10), Rječnik biblijske teologije, Kršćanska sadašnjost, Zagreb 1993., str. 1208.

95 „Ne vi nećete umrijeti.“ (Postanak 3:4)

96 Mk.12.25 
onih koji vjeruju, što na kraju zavisi od Boga. ${ }^{97}$ Ali na kraju, duh je onaj koji oživljava ${ }^{98}$ a ne tijelo, jer ako po tïjelu živite, umrïet ćete ${ }^{99}$, konačna je preporuka. Novozavjetno kršćanstvo poučava da Krist na sebe preuzima smrtnost čovjekovu, a nada i uskrsnuće i besmrtnost ostvaruje se potpunim predanjem, vjerom. Besmrtnost nije ovozemaljske, nego duhovne prirode. „Tko drži rïeč moju, sigurno neće nikada vidjeti smrti“, navodno je izjavio Isus. ${ }^{100}$

U arhaičnim društvima ljudsko je u tijesnoj vezi s božanskim, svijet mrtvih je povezan sa svijetom živih. Smrt, pogrebni običaji, mrtvi preci, nedjeljivi su sastavni dio čitave zajednice, i smrt ne znači odvajanje od živih. Groblja su također stacionirana u naseljima, pa u slučaju rata, obrana naselja uključuje i obranu mrtvih predaka. Čovjek je povezan i s prirodom, on živi s ciklusima prirode, $\mathrm{i}$ pokorava se prirodnim silama. To su društva gdje se umire u mladoj dobi, umire i puno male tek rođene djece, i doživjeti starost smatra se velikom povlasticom. U arhaičnim društvima zbog mudrosti koju stari ljudi posjeduju i zbog same duljine života koja im omogućava da razna znanja prenesu na mlađi naraštaj, odnos zajednice prema starcima je zbog toga pun poštovanja. Mudrost koju donosi starost cijeni se, jer znači dobro i korist za zajednicu. S evolucijskim razvojem društva dolazi do raslojavanja arhaične zajednice, što se odražava i na svijet bogova čiji ustroj je uvijek sličan ustroju ljudskog društva ${ }^{101}$, što opet ima utjecaja na odnos čovjeka prema svijetu mrtvih. Ljudsko se sve više udaljava od božanskog. Uz sve veće raslojavanje društva javlja se hijerarhija i među mrtvima, jednako kao i u ljudskim društvima,(„,kako na nebu tako i na zemlji““ ${ }^{102}$, ili obrnuto) gdje se nekima pripisuje veća moć nego što su ju imali za života, te im se na kraju dodjeljuju božanska svojstva. „Ljudsko se odvojilo od božanskog i iz toga su nastali bogovi; moć mrtvih postaje moć bogova, a znanje o mrtvima postaje znanje o bogovima, odnosno religija. " ${ }^{103}$ Shodno tome sve je veće uzdizanje bogova u nedokučive nebeske visine uzrok sve većeg straha od smrti, i čovjek postaje sve ponizniji prema njihovoj veličanstvenosti kojoj se obraća molitvom za vlastitu besmrtnost, a svoje jadno, malo, kratko postojanje gleda sa sve većom tugom i mrzovoljom. Uslijed toga, povezanost čovjeka s mrtvima postaje sve manja, mrtvi se sve više zaboravljaju, što se vidi i po položajima groblja koja se sele na rub naselja. Udaljavanje svijeta mrtvih od svijeta živih uzrokuje sve veći strah i zebnju zbog smrti, jer ona sad znači odvajanje od zajednice, nestajanje iz svijeta živih znači samoću.

Čovjek želi biti besmrtan poput bogova, jer svoje vlastito postojanje u odnosu na njih vidi besmislenim, te traži uskrsnuće, vječni život, što izriče vjerom u Spasenje. Pojam Spasenja postao je sadržajem mnogih religija, te je kao izraz nadanja čovjeka u mogućnost izuzeća iz procesa nestajanja, raspadanja, upravo on, u ogorčenoj borbi religije i ateizma, odigrao presudnu ulogu u

97 Enciklopedija živih religija, Nolit, Beograd 1990.

98 Ivan,6,63

99 Korinćanima, II,4

100 Iv, 8,51; Rječnik biblijske teologije, Kršćanska sadašnjost, Zagreb 1993, str. 1219

101 E. Morin, Čovjek i smrt, str. 245

102 Dio teksta kršćanske molitve Oče naš.

103 E. Morin, Čovjek i smrt, str. 243 
konačnom opredjeljenju velikog broja pojedinaca u korist religije ${ }^{104}$.Zastrašivanja vječnom lomačom, strahovlada mučenja, spaljivanja i progona, nisu toliko zaslužni za uspjeh religije kod širokog sloja ljudi, koliko je to strah od smrti. Bertrand Russell smatra strah u kome ljudska civilizacija ima svoje izvorište glavnim izvorom praznovjerja i jednim od glavnih izvora okrutnosti, te uz pomoć „politike straha“ materijalom za zajedništvo. Svladavanje straha je za njega početak mudrosti u potrazi za istinom, kao i nastojanje za vrijednim načinom života. ${ }^{105}$

U središtu vjerovanja u Spasenje je inicijacija (koju religije objašnjavaju „smrću za novo rođenje“) te postupak žrtvovanja (koji je na kraju čin prepuštanja božjoj volji, čin potpunog vjerovanja, o čemu između ostalih svjedoči biblijska priča o Abrahamu), i oni koji vjeruju, spasit će se. Ljudska patnja ima veliku ulogu pri Spasenju, jer i u procesu inicijacije i u procesu žrtvovanja koji su međusobno nedjeljivi (žrtvovanje je u svojoj biti inicijacija kojom se potvrđuje vjera i neupitna odluka stupanja na Božji put, sklapanje saveza između Boga i čovjeka), bitno obiljě̌je je upravo bol, nesreća, koje na kraju donose nagradu, izbavljenje iz Doline suza. Poigravanje ljudskom patnjom zaodjenuto u veo mistike ipak je mnogima, naravno „onima koji vjeruju“, ublažilo osjećaj tjeskobe zbog činjenice vlastite smrtnosti, a u društvenom smislu je značilo bespogovorno prihvaćanje loših uvjeta života od strane širokih slojeva ljudi koje su sve poslušno podnosili jer su znali da na kraju slijedi nagrada u obliku Spasenja, što sve zajedno ukazuje na to da je težnja čovjeka ka besmrtnosti za njega vrhovna, i najvažniji je sadržaj svih njegovih nadanja.

Religije raspolažu idejom Sudnjeg dana čije se značenje u odnosu sa smrt sastoji u nagovještaju neuništivosti. Naime, ako postoji Sudnji dan, vrijeme kada će svi ljudi pred Bogom odgovarati za sve što su učinili, i dobro i zlo, onda ipak smrt nije konačna jer nešto iza nje slijedi.

Morin $^{106}$ smatra religije spasenja lukavim izumom države kojom ona drži jedinku u pokornosti, ciljajući na najslabiju točku čovjeka - njegovu želju za besmrtnošću, jer čovjek je spreman učiniti sve da bi izbjegao smrti, pa je tako spreman i umrijeti za društvo koje mu je prerušeno u Boga obećalo vječni život.

\section{Ukidanje smrti ukinućem ega}

Morin $^{107}$ razlikuje tri perspektive poimanja smrti: osobno spasenje putem Boga, kozmičko spasenje koje se sastoji u stapanju s kozmičkim božanstvom, te skeptički, ateistički stav prema smrti. Prve dvije predlažu svojim sljedbenicima mogućnosti izbavljenja iz prijetećeg beznađa ništavila smrti, dok bi opredijeljeni za treću mogućnost, kojih je u posljednje vrijeme zbog širenja vjerovanja u moć znanosti sve više, i koji bi prema stavu religijski orijentiranih spadali u one „kojima niti Bog ne može pomoći“ iz jednostavnog razloga što ne vjeruju u njega.

104 ibid., str. 257

105 Russell, Bertrand, An Outline of Intelectual Rubbish, 1950, u Lars Tr. H. Svendsen, Strah, TIMpress, Zagreb 2010., str. 142

106 Morin, ibid., str. 304

107 ibid., str. 57 
Pozabavit ćemo se s prva dva aspekta:

Ako se odluči na spas uz Božju pomoć, od čovjeka se očekuje potpuno predavanje Božjoj volji, potpuno vjerovanje u Božju intervenciju koja će ga spasiti na neki način, ovisno o tipu religije kojoj pojedinac pripada, a princip je uvijek isti, princip prema kome čovjek neće biti naprosto rastočen u ništavilu, nego će se naći na nekom za tu priliku prikladnom mjestu od posebnog značaja, u dovoljnoj mjeri dostojnom čovjekove veličine, i u svakom slučaju se radi o nekakvom „vječnom počivalištu“, što znači da su nestajanje i raspadanje izbjegnuti. U drugom slučaju je to prepuštanje kozmičkoj energiji: cijeloga se života uvježbava tzv.“ umijeće prepuštanja“, i nakon prestanka zemaljskog života slijedi uranjanje u kozmičku energiju; čovjek postaje dio „velikog oceana“ kako se često naziva sveukupnost energije svijeta. Ustvari, radi se o učenju koje naglašava da je čovjek oduvijek bio i jest dio tog velikog oceana, samo za života to mnogi pojedinci ne vide. Upitna je sposobnost viđenja i nakon smrti, što se onda za vrijeme trajanja života neprekidno uvježbava.

U oba slučaja prepreka može biti ljudski ego koji se smatra sviješću odvojenom od božanske, osobnim unutrašnjim sklopom koji čovjeku ne dozvoljava vjerovanje bez ikakve sumnje ili preispitivanja onoga u što bi trebao vjerovati, a tako ometa i prepuštanje i spajanje s cjelinom. Ego, u sebe samog zatvoren, čovjeka odvaja od svega što ga okružuje i čini ga usamljenim, što mu onda uskraćuje mogućnosti spasa. Ego obuhvaća sve ono što je čovjek za života „postigao“, oko čega se trudio. To su sva njegova znanja, vjerovanja, umišljaji, konstrukcije, svi sadržaji njegovog uma, njegove osobnosti ,njegov „karakter“, sve što je čovjek cijeloga života s mukom stvarao, i sad bi se u času smrti toga svega trebao tek tako odreći! To nije lako, jer, "prije će se deva kroz iglene uši provući, nego bogataš ući u Kraljevstvo nebesko" ${ }^{108}$ ( tu je Isus svakako mislio na veliko bogatstvo koje je čovjek za žovota sabrao u svom umu, njegov ego, a ne na materijalno bogatstvo, kako se nerijetko pogrešno tumači). Otud pretjerano prijanjanje za život o čemu govore istočnjački mudraci.

Dok je u religijama koje propovijedaju vjerovanje da je potrebno svoju sudbinu prepustiti u božje ruke ( ,....velika je tvoja vjera. Neka ti bude kako želiš! ““109), kozmičke religije se često služe tehnikama postizanja ekstaze, stanja u kojem je pojedinac u najbližem kontaktu s kozmičkim božanskim. Yogističke meditacije, prizivanje božjih imena ili ples sufija, vježbe kontemplacije, mistični su obredi uz pomoć kojih se bar na kratko postiže stanje uma oslobođenog od misli koje su emanacija ego-programa pojedinca, (,bez-uma“, stanje utišanog uma) i koje mu onemogućavaju „kozmičko suživljavanje, zaborav svoje posebnosti i svoje slučajnosti“. ${ }^{110}$

Takvo shvaćanje nije svojstveno samo kulturama Istoka koje su u novije vrijeme na tom planu stekle najveću popularnost, nego je poznato i na Zapadu, gdje je prisutno još od vremena ranih kršćanskih mistika, a našlo je svoje mjesto i u učenjima kasnijih istraživača, primjerice Meister

$108 \mathrm{Mt}, 18: 23$

$109 \mathrm{Mt}, 15: 28$

110 Morin, ibid, str. 308 
Echkarta $^{111}$, Jacoba Bohemea ${ }^{112}$ koji je još prije više stotina godina optužio Jastvo za čovjekovu nesreću, G.I.Gurdjieffa, koji je nazvavši čovjeka pokvarenim strojem koji u svakoj situaciji reagira na mehaničan način što ga onemogućava u spoznaji i slobodi, također kruti ljudski ego proglasio krivcem za takvo stanje ${ }^{113}$, te R. W. Emersona ${ }^{114}$, E. Swedenborga ${ }^{115}$, i mnogih drugih.

U korijenu tih učenja naglasak je na važnosti potpunog i kvalitetnog življenja života, što onda i činjenicu smrti proglašava beznačajnom. Jer ako smo svi „kozmički“ ili „božji“, što onda znači što ćemo u ovom kratkotrajnom i raspadljivom, materijalnom tijelu umrijeti (!), prevladavajuce je mišljenje. Prema tom shvaćanju zadatak svakog pojedinca je što bolje iskoristiti život za osobni razvoj, a to se postiže upravo intenzivnim življenjem. Svijest o neminovnosti smrti je prema tome mogućnost za bolje razumijevanje života, i time šansa za (duhovni) rast čovjeka. Prema svjedočenjima ispitanika Raymonda Jr. Moodija ${ }^{116}$, američkog psihijatra poznatog po svojim dugogodišnjim bavljenjima fenomenom „tik do smrti“117, a radi se o pojedincima koji su iskusili blizinu smrti te doživjeli gubitak oštrih granica između ega i ne-ega čime su nestale uobičajene granice između unutrašnjeg i vanjskog svijeta, smrt nije više tako strašno iskustvo na čije bi se izbjegavanje trebalo koncentrirati cjelokupno ljudsko nastojanje, nego ono što je bitno u životu pojedinca je istraživanje mogućnosti ljudskog duha. Oslobođenje je u ostvarivanju vlastitih potencijala i tu leži tajna Spasenja. Raymond Jr. Moody smatra da je njegov rad zaslužan za promjenu općenitog stava prema smrti .

Armenski mistik i filozof Georgij Ivanovič Gurdjieff ${ }^{118}$ koji se bavio mogućnostima razvoja svijesti čovjeka, smatrao je da većina ljudi prolazi kroz život u stanju sličnom stanju sna, čega nisu svijesni. On ih naziva spavačima zbog toga što njihov prolazak kroz život nalik trajanju u stanju sna a ne bivanju u budnom stanju ostaje nepromijenjen, oni prolaze kroz život potpuno nesvjesni vlastitog postojanja, a takvi odlaze i u susret smrti koja je za njih zbog nepoznavanja života potpuna

111 Johannes /Meister/ Eckhart, 13-14-st., njemački dominikanac, teolog, filozof i mistik. Njegova učenja je godine 1329 , papa Ivan XXII proglasio heretičkim

112 Jakob Böhme, 16-17. st., njemački filozof i mistik

113 Georgij Ivanovič Gurdjieff, The World is Real only when „I am“, Penguin Books, London 1973.

114 Ralph Waldo Emerson, američki pisac, esejist i filozof, transcendentalist, u eseju „Oslanjanje na sebe samog“ („SelfReliance“) govori o ljudskoj sklonosti komformizmu, ljudskom umu koji ima takve težnje, i uzrokuje za čovjeka nesreću. Smatra važnim da se svaki pojedinac okrene sebi samom i razvija svoju individualnost.

115 Emanuel Swedenborg, švedski znanstvenik, teolog, filozof i mistik iz 18.stoljeća. Ističe slobodu ljudske volje kao najvažniju mogućnost čovjeka. U smrti se duša kristalizira i stanje u kome je pojdinac najčešće bio za života; raj i pakao su u nama, nisu nam izvana dani.

116 Raymond Moody Jr, Život poslije života. istraživanje fenomena tik do smrti, predgovor, Elisabeth Kübler Ross, pogovor Antun Vitturi, Prosvjeta, Zagreb 1986. str., 215

117 Raymond Moody, Jr., američki psihijatar, dugi niz godina bavio se fenomenom „tik do smrti“, pojavama doživljaja koje imaju pojedinci koji su u stanjima na rubu života i smrti doživjeli stanja koja su opisivali kao oblik postojanja izvan vlastitog tijela. Pri tome su opisivali susrete sa svojim voljenima koji su umrli prije njih, ili s likovima iz svoje religije.Takvi izvještaji posljednjih decenija učestalo nam pristižu iz svijeta znanosti, ili o njima saznajemo na razne načine putem svjetskih medija. Moody je, nagovještavajući mogućnost „preživljavanja“ nakon smrti, doživio veliku popularnost.

118 O radu sa svojim učiteljem pisao je ruski filozof Petr Damjanovič Ouspensky, u knjizi „U potrazi za čudesnim“, gdje je Gurdjieff glavni lik knjige, i autor ga naziva samo inicijalom, G. Tamo je također izloženo učenje o potrebi razvijanja viših stanja svijesti.

Petr Damjanovič Ouspensky, U potrazi za čudesnim, str, 179-183, www.radidiberum.org 
nepoznanica, i nije čudo što onda izaziva jezu i užas. ${ }^{119}$ Život s nepobitnošću smrti koja je njegov sastavni dio za pojedinca je izazov, poziv na „buđenje“, na koji većina ipak ostaje neosjetljiva propuštajući tako svoju životnu šansu za vlastito osvješćivanje bar u trenutku smrti. Priča o Isusu i oživljenom Lazaru bi se mogla ispričati na drugi način: da nije čudo što je Isus oživio Lazara, nego je čudo u tome što se Lazar odazvao pozivu! ${ }^{120}$

Smrt se (takvo mišljenje prevladava u istočnjačkim tradicijama) smatra šansom za učenje, prijelaznim stanjem na putovanju prema svjesnosti, „vratima“ između dva života, i „postignuce“ u smrti uvijek je posljedica života koji je pojedinac vodio, spada u domenu njegove vlastite odgovornosti. Slijedeći život vezan je za umijeće umiranja i izbora ponovnog rođenja. Umjetnost umiranja neodvojiva je od umjetnosti življenja. Prema tibetanskoj tradiciji, oni koji za života izbjegavaju pomisao o smrti „izbjegavaju praksu“.

$$
\begin{gathered}
\text { „Svi oni koji niti misle niti haju } \\
\text { Kad se glasnici smrti pojave } \\
\text { zacijelo osjećaju duge nalete patnje. }
\end{gathered}
$$

Ti koji oklijevaš i ne misliš o dolasku smrti

Posvećujući se beskorisnim djelima ovog svijeta

Ti neoprezno propuštaš svoju priliku. “121

Oslobođenje od patnje (života) i smrti ne postiže se produženjem života do beskonačnosti, nego dospijećem u stanje nirvane, potpunim nestankom.

„Zatirući rođenje i smrt,

Sigurni i sretni oni postaju." ${ }^{122}$

Učenja mistika ukazuju na negativne posljedice prevelike obuzetosti za „preživljavanjem“, i ono što treba pobijediti nije smrt već obuzetost samim sobom. Maister Eckhart ${ }^{123}$ uvodi pojam „odmaknutosti“, misli na odmaknutost od zaslijepljenosti težnjom za ostankom na životu, i kako

119 O nerazumijevanju prirode života i smrti kao osnovnom uzroku straha od smrti govori i Lama Ven. Ayang Rinpoche.

120 Osho Rajneesh, Mustard Seed, Rajneesh Foundation International, Oregon 1978.

121 Tibetanska knjiga mrtvih, CID- NOVA, Zagreb 2005., str. 51

Tibetanska knjiga mrtvih, Bardo Tödöl,“Oslobađanje slušanjem na posmrtnoj razini“ jedinstveno je djelo sakralne književnosti, spada u svete knjige, i to je ritualni posmrtni tekst koji se čita prilikom nečije smrti. Poruka je upućena živima kojima se prenosi ezoterijsko učenje o skrivenoj strani ljudske prirode. Krajnji cilj je postignuće oslobađanja iz kruga rađanja i umiranja, vezano je za karmu (moralni zakon uzroka i posljedica) i neostvarivo za one čija je karma loša. ( Tibetanska knjiga mrtvih, str. 9-10)

122 Tibetanska knjiga mrtvih, str. 52

123 Maister Eckhart, Knjiga božanske utjehe: Traktati i propovijedi, Naprijed, Zagreb 1991. 
ističe jedina stvar koja gori u paklu je djelić čovjeka koji odbija umrijeti. „Poučavam te prolaznosti“, poruka je tibetanskih mudraca. ${ }^{124}$

Odlikom mudrosti života smatra se spoznaja o neminovnosti smrti kao normalnoj pojavi. „Mudrost odiše mirisom života i smrti“, kaže stara latinska poslovica.

Takva shvaćanja, iako su oduvijek bila sadržajem učenja mistika Istoka i Zapada, postala su popularna u drugoj polovini dvadesetog stoljeća, kad je uslijed nezadovoljstva izazvanog konačnim rješenjima koja su nudile i oficijelne religije i znanost, a u velikoj mjeri pod utjecajem istočnjačkih učenja koje su se kao pomodna u to vrijeme pojavila na Zapadu, došlo do ekspanzije traganja za novim mogućnostima čovjeka.

\section{Smrt i civilizacija - umjetnost poricanja smrti}

Slijedom razmatranja o međusobnom odnošenju kulture i prirode moglo bi se govoriti i tome kako se smrt može tumačiti jezikom civilizacije.

Njemački sociolog Norbert Elias ${ }^{125} \mathrm{u}$ svom razmatranju o razvoju civilizacije kao procesu specifične promjene ljudskog ponašanja, objašnjava razvoj unutrašnje strukture ličnosti kao proces sve veće kontrole afekata koji su povezani s promjenama u društvenoj strukturi, jer sve većom diferencijacijom društva i tome odgovarajućim rastom lanca međusobne ovisnosti članova društva, raste i individualna samokontrola. Vanjska prinuda društva sve više biva internalizirana, te postaje dio čovjekove ličnosti. Iako Elias ne govori o čovjekovom doživljaju smrti, mogla bi se svakako napraviti poveznica u tom smislu da u procesu“ civilizacije" pojedinac koji postaje sve više subjekt sam sebi dovoljan i zatvara se u ljušturu koja ga odvaja od svega što se događa vani ${ }^{126}$. U svijesti čovjeka smrt postaje sve više odvojenom od života, a njeno poricanje sve sofisticiranije. Čovjek je također otupio na sliku smrti, jer je civilizacija koja se jako boji umiranja nudi kao prizor nestvaran i artificijelan, time naoko bezopasan. To je još jedan od načina kojima društvo poriče činjenicu smrti, a razvojem civilizacije razvija se i mogućnost apstrahiranja, te se dešava sve veći jaz između prirodnog, nagonskog u čovjeku ${ }^{127}$ i njegovog ponašanja.

Slijedom tog procesa, u okviru civilizacije razvila se umjetnost tabuiranja u svim segmentima života. (Reći „popu pop, a bobu bob“ nije više tako jednostavno, jer čovjek više nema smisao za jednostavno i točno izražavanje svojih misli i osjećaja. Ono što je neugodno, izbjegava se u iskazu, zaobilazi se) "Hajde da razgovaramo o nečem drugom," ${ }^{128}$ samo ne o smrti.!129

124 Soygal Rinpoche, Tibetanska knjiga mrtvih, str. 76

125 Norbert Elias, Proces civilizacije, Izdavačka knjižara Zorana Stojanovića, Sremski Karlovci 2001.

126 Norbert Elias, Proces civilizacije, str. 39

127 N. Elias, ibid.

128 Lav Nikolajevič Tolstoj, Pripovetke; Smrt Ivana Iljiča, Savremena biblioteka, Beograd 1922. str. 28

129 “U žudnjama za svjetovnim dobrima i zbog lažnosti u obiteljskim i društvenim odnosima, o smrti se kao nečemu prirodnim neizbježnom, ne govori. Bog se zaziva samo u nevoljama i u smislu stanovitog odgovora "daj-dam" moljakanja koje bi trebalo odgoditi smrt. ( L.N Tolstoj, ibid. str. 29) 
Iako je od pamtivijeka bila vječna pratilja čovjeka i tijekom povijesti središnja tema ljudske kulture, bilo da joj se čovjek prepuštao ili se borio protiv nje, smrt je danas nepoželjna, prešućivana, pomisao o njoj je potiskivana iz naših života. Smrt se uvijek događa nekom drugom, prevladavajuća je fantazma modernog čovjeka. Zapad nudi poricanje smrti1 ${ }^{130}$, a ako se već umire, onda se ne umire „naprosto“, nego se uvijek umire „od nečega“, od bolesti, nesreće. Slika smrti izjednačuje se s mehaničkom slikom kvara na nekom stroju, posljedicom nedosljednosti u rukovanju, kao da će čovjek, ako bude uzimao lijekove, nosio šal i izbjegavao vožnju automobilom, živjeti vječno! ${ }^{131}$

Poricanje smrti najočitije je u govoru, u strahu od upotrebe riječi koje je izravno imenuju ${ }^{132}$. Zamagljivanjem značenja izraza koji se odnose na smrt, čovjek prikriva i zamagljuje svoj strah i tjeskobu pred činjenicom da svakome od nas ona ipak slijedi na kraju životnog puta. Kad se govori o smrti onda se često govori o odlasku, prelasku na drugu stranu, rastanku od ovog svijeta, predavanju duše bogu, vječnom počinku, blagom snivanju u Gospodinu, upokojenju, itsl., što navodi na to da ćemo nakon životne borbe u svijetu mrtvih konačno naći svoj mir, odmoriti se. Smrt se često uspoređuje sa snom, što može asocirati na želju da se u smrt uđe lako i neprimjetno kao u san, ili nadu da je smrt slična snu, te da nakon nje slijedi buđenje u nekom drugom svijetu. ( Indijanci su na primjer koristili izraz „,ječna lovišta“, koji je drugi svijet na koji pokojnici idu kvalificirao kao bolje mjesto za boravak, u skladu s najvažnijim potrebama opstanka u svijetu živih.) U upotrebi su i malo grublji izrazi koji ironizirajući tjelesne znakove koji se odnose na smrt ili asocirajući na mjesto ukopa, unose i dozu humora u tu neminovnu i okrutnu životnu činjenicu, čime se olakšava osjećaj tjeskobe. To su na primjer izrazi: otići dva metra ispod zemlje, zabiti nos u ledinu, otegnuti papke, zijevnuti, riknuti, odapeti, otegnuti sve četiri, spakirati se u kofer, vrisnuti, ispružiti se, otići Bogu na divan, itd. Razne profesije upotrebljavaju različite izraze koji se odnose na smrt, tako na primjer pogrebnici, da bi bolje plasirali svoje proizvode mrtvački kovčeg nazivaju „vječnom kolijevkom“, dok za groblje koriste izraz „vječno polje mira“, čime se ublažava ustrašnost smrti. ${ }^{133}$ Ideologije po pitanju smrti također imaju specifične izraze, tako se za smrt u ratu koristi izraz: pasti za domovinu, položiti život na oltar domovine, pasti za bolje sutra, i tome slično, a svećenici opet, u skladu s odrednicama tipa religije kojoj pripadaju, navode različite aluzije o boljem i vječnom životu na drugom svijetu. Čini se da se spominjati smrt točnim nazivom danas smatra čak i nepristojnim, pa se na primjer kao oblik uglađenog izražavanja umjesto izraza" umrijeti” koristi riječ "preminuti”.

Postoje i različiti mitovi o smrti koji se koriste u razne svrhe, tako priča o drugom svijetu gdje ćemo se susresti sa svojim najmilijima, nastala kao izraz tjeskobe izazvane neminovnošću smrti, služi umanjenju osjećaja opće odbačenosti i samoće koja nas očekuje nakon smrti, dok je na primjer priča

130 u L.V Thomas, Antropologija smrti II, str. 189

131 Eugene Ionesco, u L.V Thomas, Antropologija smrti II , str. 22

132 Edita Hercigonja-Mikšik, Smrt u jeziku i smrt jezičnog znaka, Republika, Zagreb 2007.

133 U jednoj američkoj dokumentarnoj televizijskoj emisiji koja je govorila o trgovanju pogrebnom opremom, prodavač je, želeći naglasiti kvalitetu proizvoda naveo da su „limeni lijesovi u svakom slučaju jeftiniji, ali oni hrastovi su puno zdraviji“! 
o četrdeset prekrasnih hurija koje u rajskom vrtu čekaju hrabrog bombaša samoubojicu ideološko sredstvo kojim se hoće nekoga navesti na čin žrtvovanja sebe nekom u ratu.

Čovjek je sve više zaokupljen brigom oko poricanja smrti, koje iako sveprisutno ipak nikad nije potpuno ${ }^{134}$ Uza sve napore, umiranje je sasvim izvjesno, a iluzija odlaganja ili potiskivanja kraja koji ipak slijedi na kraju svakog puta pa ma kako on zavojit, te pun vrludanja i izbjegavanja bio, ostaje u domeni imaginarnog.

Društvo u kojem je smrt sveprisutna jer na nju podsjećaju i informacije koje sa svih strana stižu putem medija, postaje sve više neosjetljivo. Danas je smrt poruka, jedna među ostalima koje bombardiraju sa svih strana. U svakodnevnom govoru ima puno izraza koji odnose na smrt. Spominju se ekocid, tericid, homicid, etnocid, genocid, herbicid, itsl, koji su postali dio suvremenog jezika, ali čovjek je izgubio osjećaj za pravo značenje tih izraza. ${ }^{135}$ Thomas ${ }^{136}$ primjećuje da je čovjek osim što je smrtan, zbog svoje sklonosti ratovanju, ubijanju, agresivnom odnošenju prema svemu što ga okružuje, ujedno i smrtonosan! Smrt se svakodnevno plasira putem tiska, televizije, interneta ili kao fikcija u obliku umjetničkog djela, ili kao izvještaj o događanju, ali čini se da je smještena izvan vlastitog života pojedinca, nešto što se njega direktno ne tiče. Ona je predstava koje se dešava tamo negdje na nekom drugom mjestu, i tako informacija o smrti gubi na svojoj snazi, što stvara privid. Čovjek se i dalje panično boji smrti, u najnovije vrijeme možda najviše, samo pomisao o njoj potiskuje na razne načine, pa je banalizacija smrti, trivijalizacija, izraz njegovog straha a ne bezbrižnosti.

Ono što pripada području nestvarnog a podsjeća na smrt izaziva nelagodu, pa se često u filmovima horor žanra kao glavni akteri užasa koriste lutke, jer zbog toga što su napravljene tako da liče najčešće na dijete ili odraslog čovjeka, ali su nepomične, nežive, dojam koji izazivaju je dojam zaustavljenog (često grotesknog) života, podsjećaju na leš, pomno uređen i našminkan za pogreb. Posebno zastrašujuće su lutke koje koriste trbuhozborci, jer one se miču, razgovaraju, a opet su u cijelom svom performanceu nežive, te često puta u predstavama ili filmovima igraju ulogu nekog zločestog, stravičnog bića.

Thomas $^{137}$ naziva takav postupak laicizacijom smrti, što je prema njegovom shvaćanju logičan slijed odnosa prema tom fenomenu koji je tekao od desakralizacije, preko desocijalizacije, pa do stanja "preokrenute" smrti, gdje autor smatra da je u društvu gdje se smrt uzima jako ozbiljno na ontološkom polju, prenaglašena pojava njen tabuizacije te žaljenja, što na kraju na vanjskom planu dovodi do ismijavanja ili ne obraćanja previše pažnje na činjenice koje su u vezi sa smrću. Tako na primjer pogrebni obred sve više seli u „privatnu“ sferu. Pogreb je nešto što se obavlja na brzinu, u krugu obitelji, a umirući najčešće umiru po bolnicama, sami ili uz eventualnu prisutnost

$134 \mathrm{~V}$ Thomas, Antropologija smrti II, str. 240

135 Šimleša spominje naziv sredstva za zaštitu bilja „Earthcide“ (!), i nevjericu, radi li se tu o bolesnoj šali ili je naziv stvaran. „Što osjeća osoba koja kupi otrov nazvan Earthcide i pospe ga po travi gdje će mu se igrati dijete ili valjati pas koji onda uđe u kuću i legne na sofu, dok mu je glavna zanimacija buljenje u televizor“" (Šimleša, D., 2010, str. 18)

136 L.V Thomas, Antropologija smrti II, str. 16

137 L.V Thomas, Antropologija smrti II, str. 134 
bolničkog osoblja. I postupak s lešom, gdje se umrli uređuje i šminka tako da liči na živu osobu te oblači u svečanu odjeću koja je jednaka odjeći što se nosi za života, također je pokušaj poricanja smrti. Umiranje je, jednako kao što su groblja udaljena na rubove naselja, gurnuto na marginu društva, dok je ujedno s druge strane u samom centru pažnje, i to u obliku bavljenja mogućnostima izbjegavanja, preživljavanja.

\section{Kult mladosti kao novi način izbjegavanja smrti.}

Poznati teoretičar suvremenog, ,umreženog“ društva Manuel Castells ističe tri faze razvoja društva što se očituje u međusobnom odnosu prevlasti prirode i kulture. U prvoj fazi Priroda vlada nad Kulturom, što znači da je sudbina čovjeka u velikoj mjeri u vlasti prirodnih sila. U drugoj fazi dolazi do preokreta pa Kultura vlada nad Prirodom, što znači da je čovjek u velikoj mjeri ovladao svojim životom, i u trećoj fazi Kultura vlada nad Kulturom, što znači da je nastupilo informatičko društvo, i bitni odnosi u društvu se kreću iznad materijalne sfere. U umreženom društvu dešava se razbijanje biološke i društvene ritmičnosti povezane sa životnim ciklusom ${ }^{138}$, te autor predlaže hipotezu da biosocijalno zamjenjuje socio-biološko, što znači da su odnosi u društvu, prevladavajuće vrijednosti, društveni ustroj, važniji od bioloških činjenica koje probijaju svoje prijašnje granice i životne uloge više nisu biološki određene. Dihotomija mladost/snaga - starost/slabost, više ne igra presudnu ulogu u sudjelovanju u životu i odnosi se stvaraju oko novih društvenih vrijednosti među kojima su najvažniji obrazovanje, briga o karijeri i pristojnim mirovinama nakon radnog vijeka, uvjeti rada i radno vrijeme, kvaliteta života uopće. Ljudski vijek se sve više produžava, tradicionalni biološki ritam se sve više zamjenjuje trenutačnim egzistencijalnim stanjem. Slijedom takvog mišljenja Castells smatra da se starije osobe dijeli prema stupnju onemoćalosti a ne prema dobi, te da razvoj društva ide $\mathrm{u}$ tom smjeru.

Lasch ${ }^{139}$ opet smatra da se suvremeno društvo neprijateljski odnosi prema starcima, $i$ to prije svega što je pojam starosti povezan s pojmom smrti. Starenje nagovještava smrt, te je i strah od smrti usko povezan sa strahom od starenja. Jezu pred starošću i smrću koja obilježava današnjicu, iako je rezultat promatranja onoga što se u društvu dešava, $\operatorname{Lasch}^{140}$ proglašava iracionalnom zato što je rezultat pojave narcističke ličnosti koja prevladava u modernom društvu, te i samo društvo naziva narcističkim. Osnovna obilježja su mu identična obilježjima narcističke ličnosti, a prevladavajuća je sveopća pojava nedostatka unutrašnjeg izvora, kako pojedinca tako i društva, zbog čega se onda javlja potreba za divljenjem od strane drugih kao potvrda sebe samog. Suvremeno društvo ima potrebu da se drugi dive baš onim obilježjima koje polako blijede s vremenom i starenjem (ljepota, šarm, snaga, uspjeh), tako da vlada opća klima nevoljkosti prema prolaznosti mladosti. Raznim postupcima nastoji se produžiti mladost, i kao što je nekada u arhaičnim društvima bio prevladavajući kult predaka, sad je njegovo mjesto zauzeo kult mladosti.

138 Manuel Castells, Uspon i pad umreženog društva, Golden marketing, Zagreb 2000., str. 470

139 Christopher Lasch, Narcistička kultura, Naprijed, Zagreb 1986.

140 C. Lasch, Narcistička kultura, str. 239 
Strah od starosti je i strah od neuvažavanja, što odmah znači i korak bliže smrti. Mudrost staraca koja je nekad bila važna za zajednicu, sad se samo smatra utjehom starosti, ali nema bitno značenje. Nitko više ne sluša staračke tlapnje! Naime, vrijednost nakupljene životne mudrosti i znanja gubi na važnosti zbog toga što je ovo doba tehnološkog napretka, novih instrumentalnih znanja, tehnoloških promjena, znanje neprekidno zastarijeva, ono više nije isključivo prenosivo, i starija generacija više nema što dati društvu. Novi naraštaji uvijek traže nova znanja i nova rješenja za probleme, i čak je preporuka društva da se uvijek teži promjeni, novom, nevezanju, pokretljivosti u karijeri i traženju novih izazova. Strah od klopke ${ }^{141}$, strah od zamke koju društvo svakodnevno postavlja, težnja slobodi i promjeni, smatra se bitnom kulturnom vrijednošću. Smatra se da je ograničenje slobode ujedno i ograničenje razvoja, što na kraju može značiti stagnaciju i starenje. Na sve strane se pojedinca upozorava da se ne uhvati u proces starenja jer starost je živuća smrt!

„Djed više nije čudesno biće koje je smrt zaboravila i kojem se odaje duboko poštovanje." ${ }^{142} \mathrm{U}$ današnjim porodicama zbog duljeg životnog vijeka postoje već po tri generacije pa biti star nije nešto posebno. Ključne pozicije društva ostaju sve duže u rukama starijih, što je postalo društveni problem od velikog značaja.

Razvile su se nove profesije koje se bave problemom starosti (gerijatrija, gerontologija, genetski inženjering, plastična kirurgija, kirurgija koja se bavi transplantacijom organa, krionika), a cilj im je produženje života koliko god je to moguće.

„Opće klima u društvu je terapeutska, a ne religiozna!“"143 Morin ${ }^{144}$ takvo stanje naziva općom „obesvećenošću“ svijeta. Vjeru u Boga zamjenjuje vjera u Znanost. Najvažnija briga čovjeka je dobro zdravlje, što odmah znači i dulji život. Smrt se tretira kao bolest, umirući odlaze u bolnice, gdje im se različitim medicinskim postupcima nastoji produžiti život što je moguće više. Na snazi je kult mladosti, kult tijela. Sve se čini da bi tijelo što dulje izgledalo mlado, jer svako prepuštanje razornom djelovanju godina odmah se tumači i kao prepuštanje raljama smrti. Društvo je opsjednuto različitim strahovima: strahom od raka, pušenja, hrane, pića, zraka, baziranima na strahu od smrti. U modi je krilatica da je i živjeti opasno! „Survival book“ novi je Novi zavjet modernog čovjeka!

Bolest je nepoželjna, jer također navodi na pomisao o mogućnosti smrti. Da bismo izbjegli nelagodu uobičajeno je ponašanje - zazirati od svakoga tko je dugo i teško bolestan. Cioran ${ }^{145}$ ističe da dok smo zdravi imamo osjećaj da ne postojimo, ne razmišljamo o smrti, i bolesnik koji je izbačen iz tog stanja čezne za ništavilom zdravlja, za neznanjem. „Očajan je što zna da je u svakom trenutku suočen sa cijelim univerzumom, bez ikakve mogućnosti da mu bude dijelom, da se u njemu izgubi“. On smatra da smrti gledaju u oči rijetki pojedinci koji „nakon što su shvatili nepogodnosti zdravlja“ odbijaju poduzeti bilo što da bi je izbjegli ili savladali.

141 C. Lasch, Narcistička kultura, str. 51

142 L.V Thomas, Antropologija smrti II, str. 210

143 Christopher Lasch, Narcistička kultura, Naprijed, Zagreb 1986., str. 7

144 E. Morin, Čovjek i smrt

145 Emile, Michel, Cioran, Volja k nemoći, Pregled raspadanja, Demetra, Zagreb 1995., str. 189 
Novo doba je vrijeme velikog napretka znanosti koja se bavi čovjekom, ali još uvijek i neznanja o produženju života prema željama čovjeka. "Nijedno doba nije poznavalo takvu svijest o sebi. Mnogo znamo, a opet smo ništa“". ${ }^{146}$

Suvremena medicina u čije ruke svoje nade u besmrtnost polaže suvremeni čovjek, koji je uza sav strah obuzet mišlju da ipak na neki način može odagnati smrt, sve više se bavi problemom produženja života pod svaku cijenu, tako se uz različita eksperimentiranja s transplantacijama organa sve više razvija proizvodnja ljudskih nadomjestaka, proteza ${ }^{147}$ „Protezacija“ društva pretvara ljudsko tijelo u robu, proizvod koji se troši, i tako nada u besmrtnost također postaje jedna od roba na tržištu. Thomas ${ }^{148}$ takav stav objašnjava promjenama u društvenim strukturama, posebice u porodici, te razvoju kapitalističke civilizacije zasnovane na profitu, gdje se život i smrt u okviru termina „troškova života“ i „,troškova smrti“, smatraju dijelovima mehanizma koji radi po sistemu isplativosti i dobiti, $\mathrm{i}$ smisao postojanja starosti i smrti je - novac. U proces funkcioniranja „industrije smrti“ koja se bavi ostvarivanjem profita u svemu što je u vezi s umiranjem (u to spada pogrebna oprema, liječenje umirućih, prodaja grobnih mjesta) uključena je i „industrija podmlađivanja“ koja zarađuje na različitim preparatima, vitaminima, serumima, postupcima u cilju održavanja stanja organizma što dalje od stanja koje podsjeća na blizinu smrti.

Čovjek je izumio različita sredstva za borbu protiv smrti, osvojio je svoje pravo na mladost, učenje, rad, zabavu, mirovinu, razna dobra. ${ }^{149}$ Što je život razvojem tehnologije i medicine postao sigurniji, dulji, udobniji, on se sve više grčevito drži za njega i ne želi pomišljati na smrt. ${ }^{150}$

Biti bolestan, patiti, starjeti, znači pripremati se za smrt. Bolest i patnja, jednako kao i tugovanje za umrlima smatraju se izrazito nepoželjnima jer podsjećaju na vlastitu smrtnost, a tu pomisao moderan čovjek svakako želi izbjeći.

Čovjek je izumio postupke kojima „preskače“ smrt, na primjer zamrzavanje tijela do nekih boljih vremena kad će uz napredak medicine oživljavanje biti moguće, ili zamrzavanje sperme za neku posthumanu oplodnju, a također ima i slučajeva vjenčanja pri kojemu je jedan od partnera već neko vrijeme mrtav. ${ }^{151}$

Čovjek je izgubio osjećaj za povijesno vrijeme, povijesni kontinuitet, za prošlost i budućnost, on poznaje samo trenutak sadašnji, i u njemu se želi osjećati što je moguće vitalnijim i mladolikijim, jer u takvoj situaciji stari ljudi su suvišni. Ostarjeti, znači biti isključen iz društva (Morin ${ }^{152}$ to naziva

146 E. M.Cioran, Volja k nemoći, Pregled raspadanja, str. 189

147 Jacques Attali, Kanibalski poredak, Globus, Zagreb 1984., str. 13

148 Louis Vincent Thomas, Antropologija smrti II, Prosveta, Beograd 1980., str. 133

149 L.V.Thomas, Antropologija smrti II , str. 211

150 „Preveliko prijanjanje za materijalni svijet““, primijetio bi Lama čije su riječi navedene na početku teksta.

151 Nedavno se u dnevnom tisku pojavio napis o vjenčanju djevojke i njenog mrtvog zaručnika. Desilo se to u Francuskoj, a uz dozvolu predsjednika Sarkozyja, uz napomenu da je u takvom slučaju vjenčanje moguće ako se dokaže da je planirano za pokojnikova života. (,24 sata“, 29. 06. 2011.)

152 ibid. 
„društvenom smrću“), i čovjek se svim silama trudi da to izbjegne. („Oče, neka me zaobiđe ovaj kalež“, zavapio bi Isus modernog doba ali misleći pri tom na starenje i društvenu smrt!) Pošto je izgubio osjećaj za povijesni kontinuitet, pojedinac živi samo za sebe, izbjegavajući čak i potomstvo, jer potomstvo smatra vlastitom konkurencijom koja će ga na kraju istisnuti i društvene scene, a ne kako je to prije bilo uvriježeno, produžetkom vlastitog života. Zbog ubrzanog porasta broja stanovništva mjesta na Planeti je malo, puno manje nego prije, čovjek se prvenstveno očajnički drži vlastitog života koji ne želi izgubiti. To je izraz tjeskobe cjelokupnog društva, smatra Lasch ${ }^{153}$ koje više ne vjeruje i ne vidi da ima budućnosti.

\section{Duhovnost i smrt u ozračju konzumerizma}

Robert Torre ${ }^{154}$ govori o trendu New age kulture u kojoj se pojavio veliki broj knjiga o samopomoći (self-help books), vremenu gdje cvjeta industrija zdravlja, te se čini da se tu radi o religiji novog doba u kojoj su liječnici zamijenili svećenike. Stalno se populariziraju verzije najboljeg mogućeg života, te cvjeta trgovina različitim tehnikama postizanja više razine samosvijesti, samospoznaje kao vrhunskog samoostvarenja i sigurnog puta k sreći, čemu svaki pojedinac, a uz pomoć moćnog konzumerističkog aparata treba stremiti. Nude se različiti programi u cilju očuvanja zdravlja i vitalnosti, te psihičke stabilnosti. Tehnike „prosvjetljenja“ bazirane na tradiciji istočnih religija (tečajevi yoge i meditacije, tečajevi autentičnosti i svjesnosti, tečajevi čuda, orijentalnih plesova, borilačkih vještina, čak i tečajevi umiranja iznikli na tradiciji Tibeta) svoju afirmaciju u zapadnom društvu duguju upravo općem strahu od starenja i smrti kojim je Zapad zahvaćen. Na smrt i starost se ne smije niti pomišljati i umjesto toga se nude programi pozitivnog mišljenja, što bi ukazivalo na to da se razmišljanje o smrti smatra negativnim. „Think positive, think pink“ - riječi su koje se mogu vidjeti na sve strane, pa i otisnute na odjeći, putnim torbama, školskim bilježnicama. Moć pozitivnog mišljenja izjednačuje se s moći duha, što je onda pravi recept za dugovječnost. U modi su različiti priručnici popularnog naziva „Survival Book“, koji sadrže praktične savjete o tome kako ostati mlad i zdrav, kako preživjeti, što sugerira naslov, a u dubini poruke je izražena nada u besmrtnost. ${ }^{155}$

Konzumeristička teologija nudi Spasenje kroz instant recepte najboljeg mogućeg života. Ideologizirani marketing nudi svoje proizvode, uvjerenja, preporuke za formiranje životnog stava u skladu s ekonomskim poretkom čiji je agent, a pod krinkom duhovnih tradicija i njihovih dostignuća. Trivijalizirani put mudraca, crtić o najboljem životu, priručnik je, knjiga uputa o tome kako živjeti i što činiti da bi život bio uspješniji, a smrt daleka i laka. Podsjeća to na srednjovjekovne priručnike za umiranje, namijenjene katoličkim vjernicima kakvi su se negdje u 15. stoljeću pojavili na Zapadu.

153 C. Lasch, Narcistička kultura, str. 50

154 Robert Torre, zagrebački psihijatar i pisac

155 C. Lasch, Narcistička kultura 
Vodič na putu ususret smrti, „vodičza upravljanje završnim, finalnim periodom u nečijem životu“ “456, koji je u svom naslovu često sadržavao riječi ars moriendi (lat. ars u smislu umjetnosti kao vještine). Ars moriendi vs. ars vivendi, jer sudbina svakog pojedinca u činu umiranja determinirana je stanjem duše koja napušta tijelo. Dakle vrlo slično kao i u svim drugim tradicijama i ozbiljnim učenjima koja se bave smrću. Ars vivendi fokusirana je na život bez grijeha, jer grijeh je ustvari pogreška koju iz razloga neznanja čini nedovoljno prosvijećen i manjkavo upućen čovjek, a fokus je na procesu čišcenja duše, dakle na pripremu pojedinca na ono što slijedi na kraju. U ti okvirima kršćanstvo kao i sve druge duhovne tradicije poučava da niti jedna smrt nije zla ako joj prethodi dobar život ${ }^{157}$.

U konzumerističkoj eri dobrim životom se smatra lijepo i lagodno življenje provedeno u blagoslovljenom okruženju materijalne udobnosti, ali i u bavljenju tzv. „radom na sebi“, što je neophodno. Samorazvoj se proklamira kao magični ključ koji vodi Spasenju. U novo doba, iako je to ako gledamo povijesno post-magijsko vrijeme, ima još puno magije: magije pozitivnog mišljenja, newageovske duhovnosti koja obiluje raznim meditacijskim tehnikama, režimima prehrane, literaturom, guruima, a sve neprekidno trivijalizira stara učenja, $i$,prilagođava“ ih suvremenom čovjeku, pojednostavljuje, skraćuje, na isti način kao što se na primjer klasična i vrijedna književna djela pojednostavljuju da bi bila dostupna svakome tko nije baš spreman baš čitati. Samorazvoj i duhovnost za sve! Instant, brzo i efikasno! Sve se nalazi u ponudama, akcijama različitih proizvoda u tu svrhu, kreiranih zbog uspješne prodaje. Danas se sasvim lijepo trguje sa sviješću o sebi, nekad cjelovite duhovne tradicije danas su rascjepkane a komadići su lijepo upakirani instant komercijalni artefakti. Ničega previše da ne bi postalo zamorno, da ne bi odbilo potencijalnog klijenta. Čovjek, pojedinac, u svakoj životnoj aktivnosti, svemu što čini ili poduzima, sveden je na razinu klijenta! Komercijalizacija i nerazumijevanje tradicijskih učenja ipak ne znači da su ona nepotrebna, ali su suvremenom čovjeku zbog brzine življenja, zbog opće umreženosti i svekolike povezanosti koja ne ostavlja prostora samostalnom mišljenju niti bavljenju bilo čime što bi zadiralo dublje od površine ili tražilo više vremena, prostora, „udubljivanja“. Ali što onda, što poduzeti! I kao da se sve vrti u istom krugu odgovor je opet isti, isti kao i u odjeljku prije ovog - razvijati samosvijest, inzistirati na samorazvoju. A što onda činiti, što i kako poduzeti? Nema točnih uputa, nema dogovora.

\section{Smrt i katastrofe. Gdje se sakrila ideja o besmrtnosti?}

Kad se umire više nego što je uobičajeno, strah od smrti se pojačava jer naprosto s brojem mrtvih raste dojam njene neminovnosti i blizine. Smrt se utjelovljuje, u-životvoruje. Iz domene svijesti prelazi u život. I sama ideja besmrtnosti koja je vjekovima pokretačka snaga svih čovjekovih postupaka i akcija u cilju negiranja i zataškavanja svijesti o smrti, sad se negdje zavukla, sakrila, i ustupila mjesto ideji golog opstanka u trenutku sadašnjem, ovdje i sad. Najvažnije je preživjeti aktualnu katastrofu, a o besmrtnosti ćemo kasnije, ako opstanemo!.

$156 \mathrm{New}$ Catholic Encyclopedia, Ars moriendi, https://www.encyclopedia.com/religion/encyclopedias-almanacs-transcripts-and-maps/ars-moriendi, 2021.

157 Ibid. 
U uvjetima bez katastrofa i učestalih umiranja, kao što je već rečeno, smrt se gura u stranu, o njoj se ne razmišlja, to je nešto što ima biti ali nismo bliski sa sviješću o tome. No, u vrijeme kad je u društvenom okruženju pojava smrti učestala, kad postoji ugroza koja stalno na tu činjenicu podsjeća, kad je naprosto umrlih sve više, onda više nije moguće svijest o smrti „gurnuti pod tepih“, jer, previše je ima svuda i na sve strane. Ona je aktualni realitet. Sadržaj je svakodnevnih medijskih izvještaja, dio je uputa o ponašanju u uvjetima prijeteće smrti, „epidemiološkim uvjetima“, pa nas svakodnevni život i model ponašanja koji moramo slijediti, „mjere“ kojih se moramo pridržavati neprekidno podsjećaju na to. Kako se život mijenja u uvjetima kad su smrtni slučajevi češći, smrt bliža? I sam taj izraz „smrtni slučaj“ koji sugerira kao da je smrt nešto što se dešava slučajno a ne ingredijentni dio stvarnosti, čovjekovog postojanja na Zemlji, sad gubi na svojoj razigranoj lepršavosti. Smrt više nije, kao što se iz medijskih izvještaja može vidjeti - „slučaj“, nešto što je akcidentalno, nego je tu, prisutna, na svom pravom mjestu, dio je života. U vrijeme velikih katastrofa, epidemija i potresa (kao sad u godinama 2020. i 2021.), elementarnih nepogoda, ratova, čini sa de vreba sa svih strana. Smrt je medijska senzacija! Čitaju se novine i prate vijesti o kretanjima epidemije, postotcima, o broju oboljelih, umrlih. Broj umrlih, to je ono što nas najviše zanima, i zbog čega smo bez pogovora spremni odustati od aktivnosti, sudjelovanja u životu. U vrijeme velikih katastrofa život se gasi, a u strahu od kako se sad pokazuje „realne smrti“ koja vreba iza svakog ugla, mi pristajemo na sve, samo kako ne bismo bili dio crne statistike, „broja mrtvih“ koji se dnevno pojavljuje u medijima. Uz pomoć straha od smrti moguće je zaustaviti život, staviti ga na čekanje, poziciju stand-by, ograničiti svaku aktivnost, oblikovati ponašanje ljudi, pa je zato strah od smrti i moćno sredstvo kontrole i vladanja. Ako se ne ponašate u skladu s pravilima uspostavljenim zbog, primjerice epidemije, bit ćete kažnjeni. Razboljeti ćete se i po svoj prilici i umrijeti.

Ugroza vlastite sigurnosti je već odavno moćno pokretačko sredstvo moći, nešto što će podanike potjerati u rat protiv neprijatelja koji ga ugrožava, i često su te „ugroze“ montirane od stane vlastitih centara moći da bi se mobiliziralo članove društva i pokrenuo rat. Svaki rat je za njegove sudionike s bilo koje strane bojnog polje - obrambeni.

\section{Covid 19, 2020 - 2021.}

Sad se ta strategija pokazuje u jednakom sjaju i moći u slučaju epidemije virusa Covid 19 koja je u ovo vrijeme zavladala na planeti, i pokazala se moćnim sredstvom usmjeravanja ponašanja ljudi ,kontrole, uspostavljanja novih, često ograničavajućih pravila. U strahu od bolesti i smrti članovi društva pristaju na pravila, ali tu se javlja i pitanje povjerenja. Ako sve predugo traje a umire se i dalje, onda slabi povjerenje prema onima koji tumače situaciju i postavljaju pravila. Značaj eksperata postaje sve veći. Laici ne znaju puno o epidemijama, ne barataju vlastitim informacijamai spoznajama o prirodi bolesti. To su situacije kad eksperti stupaju na scenu. Za oblikovanje stvarnosti važna je uloga „tumača“, gurua koji će kao čovjek od znanja, autoritet, uliti nešto hrabrosti članovima društva i biti izvor informacija, slično kao što je to bio šaman u plemenskim zajednicama. 
Uloga medija je ključna. Mediji objavljuju vijesti gdje se prikazuju konvoji kamiona natovarenih truplima umrlih koji se kroz maglu i sivilo probijaju prema nekom prostoru gdje ce biti prostora za pokapanje mrtvih, jer u nekim gradovima to više nije moguće. Smrt do smrti u pravilnom nizu. Kataklizmički je ugođaj. Ugođaj kakav bi mogli zamisliti u slučaju kuge u srednjem vijeku. Brojna mrtva tijela koja treba negdje zbrinuti, jer toliko ih je već da se nema kamo s njima, i prestrašeni ljudi koji su se zabarikadirali u svojim nastambama i prestravljeno ćire kroz zamagljene prozorčiće ne bi li preduhitrili Bolest i Smrt koje im mogu pokucati na vrata. Mediji danas „vedre i oblače“, moglo bi s reći, Kada treba malo obuzdati epidemiju i prizemljiti kretanje ljudi, pojačati ograničavanja, onda mediji grme o ugrozi, a kada se treba desiti obrnuto (često su ta obuzdavanja i popuštanja više u vezi s potrebama društvene situacije nego sa stvarnim stanjem) onda mediji stvaraju sjajnu sliku situacije. Vježbanje života, vježbanje mogućnosti upravljanja članovima društva, i takvi se glasovi čuju u javnosti ili po kuloarima što je češće - jer vrag ne spava, kako se kaže, ali bolje je ne govoriti previše, šuška se.

Zbog prijeteće smrti i ograničavanja kojima se smrt želi preduhitriti, u društvu dolaze u žižu interesa rasprave o demokraciji u uvjetima kontrole i ograničavanja slobode građana. Postavlja se pitanje je dolazi li zbog straha od smrti u pitanje i demokracija u svijetu? Hoće li se građani odreći dijela svojih sloboda u zamjenu za životnu sigurnost?

Vidjet ćemo ako epidemije potraju, ako se katastrofe nastave, hoće li se zbog straha od smrti javiti potreba za čvršćom rukom na koju će se moći prebaciti osobna odgovornost a u svrhu zaštite?

\section{Zaključak}

Tijekom povijesne transformacije čovjekovog stava prema smrti misao koja na nov način govori o tom fenomenu razvila se u 18.stoljeću ${ }^{158}$ kao rezultat pojave građanske klase, procvata prirodnih znanosti nakon Descartesa i Bacona, udaljavanja od svega što se smatra natprirodnim, odvajanja humanističkih znanosti, te pridavanja manje važnosti religijskim stavovima. Doba prosvjećenosti, vjere u moć razuma, nagovijestilo je mogućnost čovjekove intervencije u područje smrti, ali i svijest o njegovoj nemoći. Smrt se počinje sve više smatrati neugodnom činjenicom koja nema nikakve veze sa životom, a uobičajeni postupak odnosa prema smrti postalo je njeno potiskivanje, poricanje sa sve moguće načine.

Čini se da se u suvremenosti čovjek malo više bavi smrću, da se o njoj više govori bez gnušanja, straha i - izbjegavanja. Dva su smjera u kojima se kreće suočavanje sa smrću: Jedan se oslanja na napredak medicine, znanosti, baveći se mogućnostima otkrivanja uzroka smrti i time njenog konačnog prevladavanja, a drugi je u vezi s čovjekovim vjerovanjem u postojanje „života poslije života“, koje je dobilo zamaha nakon navedene uspješnice Raymonda Jr. Moodyja ${ }^{159}$ te poplave“ newageovskih“ religija koje obiluju postupcima sjedinjenja s kozmičkim principom, kao oblikom

158 Morin, ibid. str. 351

159 Raymond Moody Jr, Život poslije života. Istraživanje fenomena tik do smrti 
besmrtnosti. Morin ${ }^{160}$ te pojave naziva samojošjednim od načina izbjegavanja suočenja sa smrću. To sve zajedno govori o tome da čovjek, uz sve moguće načine još nije prihvatio činjenicu vlastite smrtnosti, a kako ključ besmrtnosti izgleda leži u razumijevanju i prihvaćanju života, shodno tome umjesto pitanja“ ima li života poslije života“ pitanje “ ima li života prije smrti“161 prikladnije je, jer to je uputa još i drevnih mudraca, uputa za intenzivno i sadržajno življenje, a traženje odgovora na njega moglo bi čovječanstvu dati zadovoljavajuće odgovore koje traži tijekom cjelokupne svoje povijesti.

U novije vrijeme, uslijed pandemije i izazvane virusom Covid 19 i učestalijih umiranja nego što je uobičajeno, smrt postaje vidljivija, teža za izbjegavanje, o smrti se govori, u društvu se javlja strah većih razmjera. Takva situacija pred svjetske medije postavlja pitanje njihove istinitosti, etičnosti, njihove uloge u informiranju javnosti. Pokazalo se da su mediji kao i uvijek skloni senzacionalizmu, i u ovakvim kriznim uvjetima veći dio javnosti nema povjerenje u njihovu istinitost.

\section{Literatura:}

Attali, Jacques, Kanibalski poredak, Globus, Zagreb 1984.

Augustin, Sv., Ispovijesti, Kršćanska sadašnjost, Zagreb 2010.

Castells, Manuel, Uspon i pad umreženog društva, Golden marketing, Zagreb 2000.

Cioran, Emil, Michel, Volja knemoći, Pregled raspadanja, Demetra, Zagreb 1995.

Durkheim, Emile, Elementarni oblici religijjkog života, Prosveta, Beograd 1982.

Eagleton, Terry, Ideja kulture, Jesenski i Turk, Zagreb 2002.

Eagleton, Terry, Teorija i nakon nje, Algoritam, Zagreb 2005.

Eckhart, Meister, Knjiga božanske utjehe: Traktati i propovijedi, Naprijed, Zagreb 1991.

Elias, Norbert, Proces civilizacije, Izdavačka knjižara Zorana Stojanovića, Sremski Karlovci Novi Sad 2001.

Enciklopedija živih religïa, Nolit, Beograd 1990.

Frankl, Vitor, Nečujan vapaj za smislom, Naprijed, Zagreb 1987.

Freud, Sigmund, Eseji iz kulture i umetnosti, Matica srpska, Beograd 1970.

Fromm, Erich, Čovjek za sebe, Naprijed, Zagreb 1977.

Gurdjieff, Georgij, Ivanovič, The World is Real only when „I am“, Penguin Books, London 1973.

Hercigonja-Mikšik, Edita, Smrt u jeziku i smrt jezičnog znaka, Republika, Zagreb 2007.

160 ibid.

$161 \mathrm{Na}$ tom je tragu knjiga R. Torrea, Ima li živote prije smrti 
Jung, Carl, Gustav, Sjećanja, snovi, razmišljanja, Fabula Nova, Zagreb 2004.

Lane, Nick, Uspon života, Planetopija, Zagreb 2012.

Lasch, Christopher, Narcistička kultura, Naprijed, Zagreb 1986.

Miličinski, Maja, Filozofija i smrt, CID - NOVA, Zagreb 2008.

Moody, Jr. Raymond, Život poslije života. Istraživanje fenomena tik do smrti, Prosvjeta, Zagreb 1984.

Morin, Edgar, Čovjek i smrt, Scarabeus-naklada, Zagreb 2005.

Morin, Edgar, Izgubljena paradigma, Scarabeus-naklada, Zagreb 2005.

New Catholic Encyclopedia, Ars moriendi, https://www.encyclopedia.com/religion/encyclopediasalmanacs-transcripts-and-maps/ars-moriendi, 2021.

Rajneesh, Osho, Mustard Seed, Rajneesh Foundation International, Oregon 1978.

Rječnik biblijske teologije, Kršćanska sadašnjost, Zagreb 1993.

Soygal Rinpoche, Tibetanska knjiga mrtvih, CID- NOVA, Zagreb 2005.

Svendsen, Lars, .Fr. H., Strah, TIMpress, Zagreb 2010.

Šimleša, Dražen, Ekološki otisak, TIM press/ Institut društvenih znanosti Ivo Pilar, Zagreb 2010-

Thomas, Louis, Vincent, Antropologija smrti I i II, Prosveta, Beograd 1980.

Thomas, Louis, Vincent, Smrt danas, XX vek, Beograd 1989.

Tolstoj, Lav, Nikolajevič, Pripovetke; Smrt Ivana Iljiča, Savremena biblioteka, Beograd 1922.

Tomašević, Luka, Do kada produživati život?, Služba Božja, 45,br.2, Zagreb 2004., str. 143-146

Torre, Robert, Ima li života prije smrti. Iskustvo prvog lica, Media bar, Zagreb 2018.

Weber, Max, Sociologija religije, Zagreb, KruZak, Zagreb 2000. 


\title{
Fear of Death and Striving for Immortality - Eternal Paradygm of Man's Confrontation With Death
}

\begin{abstract}
Through history, man is followed by death, that despite of the fact that we are mortal, is not available to human experience, which has always caused various speculations on its nature, and the need for an explanation of what comes after. Fear of death is fear of the unknown, dissolution, disappearance. Relationship to death, as well as man's conception of the world, is consistent with the state of society, from the profound connection between life and death in archaic times, to the increasing separation, which is consistent with the basic dichotomy that characterizes the human mind, and is growing. The individual is more and more losing a sense of historical time, continuity, and connection of existence, and is desperately clinging to life. The eternal striving for immortality, before in the domain of religion, now is transferred of the faith in the success of science. The new age is characterized by avoidance of disease and aging, the cult of ancestors has been replaced by the cult of being young, and as part of man's focus on overcoming death, the need of self-development is highlighted, as the only chance of reconciliation with the fact of man's own mortality.
\end{abstract}

Key words: death, denial of death, fear of death, culture of being young, selfdevelopment, pandemic.

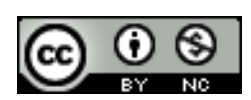

This journal is open access and this work is licensed under a Creative Commons Attribution-NonCommercial 4.0 International License. 